\title{
“COLLABORATORS IN THE GREAT CAUSE OF LIBERTY AND FELLOWSHIP": Whitmania as an Intercultural Phenomenon
}

\author{
WALTER GRÜNZWEIG
}

WHITMAN'S RECEPTION and influence abroad have been examined in numerous studies: Harold Blodgett's book on Whitman's fortune in Great Britain ${ }^{1}$ and Harry Law-Robertson's less successful dissertation on Whitman in Germany ${ }^{2}$ are among the earlier works dealing with the topic, while Betsy Erkkila's fine study on Whitman in France ${ }^{3}$ was published only a few years ago. Shorter studies exist for almost every European and a number of non-European cultures. A special 1972 issue of the Walt Whitman Review emphasized the highly international character of Whitman reception ${ }^{4}$ and a recent conference, held in Camden in 1986, demonstrated that there is indeed a continuing tradition of Whitman reception in widely divergent cultures. ${ }^{5}$

However, such studies have so far dealt only with individual cultures, and they provide an international focus only through a patchwork of individual chapters describing Whitman's reception in the various countries. Even Whitman's highly competent biographer, the Danish critic Frederik Schyberg, who devoted a whole chapter to "Whitman in World Literature" as early as $1933,{ }^{6}$ failed to describe the global Whitman reception as an intercultural phenomenon. Whitman reception in individual cultures did not occur in national isolation; the phenomenon needs to be comprehended as a highly interactive, dynamic process occurring between individuals of different cultures. The "fellowship" of Whitmanites throughout the world was often a closely knit group of people who knew each other and were very much aware of each other's interests and activities.

The familiar bi-cultural model, which investigates Whitman's fortune as an exchange between America and another culture, must be abandoned in favor of intercultural studies looking at the whole network of relationships between Whitmanites from various countries - truly a gigantic task for which studies of Whitman in individual cultures are of course the prerequisite. But even studies investigating Whitman's reception in one culture should keep an eye out for the intercultural context at large. ${ }^{7}$ Then, on a second, multicultural level, studies are needed of global Whitman reception as an interchange between individuals from many cultures. In view of the intercultural outlook of the U. S. "Fellowship," such a perspective is important even for studies of the "domestic" reception of Whitman. After all, it is not the same whether one ascribes to a poet an essentially local, "homey" significance, or whether one attempts to create a poet-prophet as the crystallizing point of a new religion. 
Indeed, while Whitman's texts have taken on some divergent meanings in various countries as a result of cultural differences, it is remarkable how many similarities in textual interpretation there are from one culture to the next. Biographical interpretation has in large part been consistent too, and such continuity has led to a fascinating and complex blend of various cultural responses. The cross-cultural similarities are not so much a consequence of some indisputable message emerging from Whitman's texts (or of the consistently eccentric personality of the poet supposedly packaged therein), but the result of a very effective propagandistic effort stimulated by Whitman's admirers and ultimately initiated by Whitman himself.

Whitman's prominent use of Emerson's greetings "at the beginning of a great career" is a well-known fact of literary history today, as are the early anonymous and pseudonymous reviews of his works by himself. It is less well-known, however, that during Whitman's later life, the poet and his loyal admirers ran an almost professional public relations office which was active on an international scale. Traubel's volumes on Walt Whitman in Camden provide ample information about such contacts, as do the lists documenting Whitman's correspondence.

This busy public relations campaign was waged in Germany quite early. In 1868, Ferdinand Freiligrath, a prominent German revolutionary poet later exiled to Britain, who first introduced Whitman to a German audience in the reputable daily Augsburger Allgemeine Zeitung, ${ }^{8}$ was the lucky recipient of an unexpected wealth of Whitman materials. In a letter to his daughter, he writes:

Today a letter arrived from Washington from a friend of Walt Whitman's-[William Douglas] O'Connor. My article on W. W. [in the Augsburger Allgemeine Zeitung] has, as I must conclude now, been widely acknowledged in America. It has been translated and published in many newspapers. Now this friend of the poet announces a copy (so far not yet received) of the original edition of Leaves of Grass as a present from this curious W. W. Furthermore, I am supposed to receive a number of other books and pamphlets [on Whitman] including a magazine with the translation of my article. ... The letter which I received today has thirty-two pages ... and contains much that is of interest with regard to Whitman, including clarifications concerning the various allegations made against him. The writer is of course an enthusiastic supporter of this strange bird. 9

Almost certainly, O'Connor's lengthy letter ${ }^{10}$ propagated the myth of Whitman as the "Good Gray Poet" and Christlike figure, which this early disciple of Whitman (along with the poet himself) was so eager to spread throughout the U.S.A. and the world.

Not all Germans, however, reacted with Freiligrath's quiet amusement. Eduard Bertz, for example, a Berlin-based writer and self-declared specialist on Whitman's "sexual anomaly," had at first been an enthusiastic supporter of Whitman. On the occasion of the poet's seventieth birthday, he wrote an exuberant review for the Deutsche Presse, published by the German writers' union with Bertz as assistant editor. Later Bertz claimed to have been 
drowned by a flood of materials received from Whitman's public relations office as a result of this article. According to later testimony (not entirely in agreement with statements made as late as 1903), Bertz considered this to be entirely in bad taste11 and turned into an "apostate" of the "Whitman cult."12

Obviously, Whitman was behind these propagandistic efforts carried out by his friends and supporters. He attempted in this way to shape his image as a person and writer and thereby to influence his reception abroad, and it is therefore not surprising that similar estimates of Whitman appear in a variety of different countries. The executors of Whitman's estate, especially Horace Traubel and R. M. Bucke, continued, intensified, and professionalized these efforts following the poet's death. Significantly, the organization founded to sponsor these activities was called the "Whitman Fellowship International" and Traubel, the secretary, as well as his friends, were indeed busy sending letters, leaflets, and love across the Atlantic and other seas.

I would like to offer a case study to demonstrate how European reception of Whitman was influenced by his American apostles organized in the "Fellowship" and how Europeans of different nationalities communicated with each other about Walt Whitman. My work is based on recent findings among the Johannes Schlaf Papers in the town archive of Querfurt, GDR,13 a very limited but interesting body of material. From a variety of angles, the Schlaf papers give us insight into the complexity of the relationships among the Whitmanites of the world.

The well-known German poet and dramatist Johannes Schlaf (18621941), one of the founders of the naturalist school of German drama and generally recognized as the leading Whitmanite in Germany, ${ }^{14}$ was offered plentiful assistance from the Camden group. The following letter to Schlaf from Traubel is characteristic:

You may depend upon me. I will help you all I can. I am sending you a little book today. You will hear from me again and again. I write now to say only this general thing. For I want you to feel assured ... that I love and know you for the things that you have already said about Whitman and for the things that you propose to do on his behalf. ${ }^{15}$

Traubel "loved and knew" Schlaf for his Whitman activities even before the German's publication of a small monograph on Whitman ${ }^{16}$ and before the publication of Schlaf's translation in the popular Reclam series. ${ }^{17}$ All of his activities were closely followed and appraised by members of the Fellowship and by Traubel's personal friends.

The free-verse poet and Whitman disciple Ernest Crosby, for example, who knew German, read Schlaf's 1904 monograph which included some translations, and he immediately and lavishly praised it:

My dear Herr Schlaf:

I received your book the day before yesterday and have read it through with the greatest interest. It seems to me the best thing yet written on Whitman. I will suggest to Traubel that he 
have it translated and published in the Conservator. Mrs. von Ende ${ }^{18}$ would doubtless be glad to do the translating. It is wonderful how well Whitman translates into German. It hardly loses anything in the process. I am not sure that sometimes it does not gain. ${ }^{19}$

On the other hand, Crosby was quick to point out "misconceptions" and to apply "slight criticism" 20 where the official image of the poet was concerned.

Other members of the Fellowship were in touch with Schlaf who, as a well-known German dramatist and poet, promised the most effective and favorable introduction of Whitman to the German-speaking world. Schlaf's library, preserved in the picturesque castle of Querfurt, contains books by many Whitmanites such as Traubel, Crosby, Bucke, Knortz, O'Connor, and Mildred Bain, all of them inscribed to Schlaf by the authors. Good-by and Hail to Walt Whitman (1892) exists in two copies signed by Traubel.

The intensive contacts between Camden and foreign countries as well as the "monitoring" of overseas Whitman publications by members of the Fellowship as seen in the case of Schlaf suggest that the Whitman reception abroad can only be understood as a function of the interaction between Whitman and his propagandists in the U.S. on the one hand and the foreign translators, reviewers, and international audience at large on the other. The Walt Whitman Fellowship Papers also frequently refer to the contact with Europeans such as in the "Notes on the Annual Meeting," 1903, submitted by Horace Traubel:

Leon Bazalgette, of Paris, and Edward Bertz, of Berlin, have written the secretary that they could very extensively add to the Continental scope of the work, if their contributions were desired. ${ }^{21}$

Schlaf's pronouncement on Whitman as well as poetry by Schlaf and even contributions about Schlaf appeared fairly regularly in Traubel's Conservator, suggesting once more the interest on the part of the Camden group in European Whitman enthusiasts.

Thus certain models proposed by some representatives of modern reception theory who stress the exclusive importance of reader response and neglect the production side are proven inadequate in view of Whitman's international reception. Special attention must be paid to the dialectics between production and reception, not only on a theoretical, implicit level, but also because of the very real relationships between the source culture and the target culture. In looking at Whitman's fortune abroad, we will almost always have to take into consideration the American side as well (a thesis that can only be suggested here and that will have to be proven in a more extensive study).

The intercultural character of Whitman reception, however, is not only determined by the interaction between European and American Whitmanites but also by the contacts among Whitman devotees of different European countries. In the case of Johannes Schlaf, this is amply documented by the 
extensive correspondence with Whitmanites of various countries, especially France, who were often literary critics and poets in their own right. Here, Whitman reception clearly displays its supranational dimension, and it becomes obvious that it must be viewed from a national as well as an intercultural point of view.

The extensive correspondence between Johannes Schlaf and the French literary critic, poet and anarchist, Léon Bazalgette, is of special significance. Bazalgette, Whitman translator and biographer, apparently felt great admiration and even tenderness for his German colleague Schlaf, although the latter hardly shared the leftist-anarchist positions of the Frenchman. However, their common passion for Whitman stimulated a correspondence which is remarkable not only for its discussion of Whitman, but also for its assessments of younger French, German, and other poets, who were in their view part of a Whitmanesque school of writers.

In two letters to Schlaf, Bazalgette even suggested the establishment of a European branch of the Whitman Fellowship: "I asked myself often whether one should not establish in Europe a type of Walt Whitman Fellowship which was founded in the United States. ${ }^{22}$ Three years later, in 1907, he repeated his suggestion:

I ask myself whether one day we should not attempt to found in Europe an organization like the Fellowship of which H. Traubel is the secretary-with Binns, yourself, and Dr. Karl Federn [a Viennese translator of Whitman]. Thereby we could assemble all the European admirers of the poet and propagate his works. Maybe this idea could be realized one day. We will talk about it. ${ }^{23}$

Schlaf's answer was positive, and in a subsequent letter by the Frenchman, we read: "I am extremely happy that you agree to my idea about Whitman in Europe and your moral support alone will be a great help." 24 The project of a European Whitman Fellowship was never realized, but the very idea suggests how the impetus of Whitman reception was essentially transcultural in nature. The individuals joined together by Whitman's poetry were following an essentially ethical and political line of thought. While they would not have agreed on party politics, partisanship for Whitman certainly meant a commitment to spiritual renewal (whatever this meant in practical terms)-renewal not only for one particular country but for mankind as a whole.

This idea is very much part of the Frenchman's letters to Schlaf. Bazalgette hoped that Whitman's introduction to France would benefit a new school of French writers: "I hope thus and I know that Whitman's revelation to France will have a positive effect on the younger generation." 25 At the same time, he took an active interest in Schlaf's translation of Leaves of Grass into German, in effect hoping that the success of the movement in one country would further the "cause" in the others: 
I understand fully the importance which must be attributed to Whitman's introduction in the Reclam edition: soon, the poet will have more admirers in Germany than in America. . . . Here we have the 4th German translation of Leaves of Grass! That says a lot. . . . ${ }^{26}$

After having been informed of Schlaf's plan to translate H. B. Binns's biography of Whitman into German, Bazalgette added to this optimistic evaluation of Whitman's success in Germany in the characteristic tone of an enthusiast: "This translation will further the knowledge of the poet-prophet in Germany whom in a few centuries, humankind will place among their Gods."27 Such quotations show how Bazalgette and Schlaf, when corresponding about Whitman, used the familiar rhetoric of the Camden group and of Traubel's Conservator. They recognized and understood each other through this messianic diction and were only too willing to spread the word about Whitman and the "Whitmanesque" school of poetry and thought that they hoped to initiate in their countries.

Bazalgette was in fact so enthusiastic about Whitman's growing popularity in Europe that he made use of a cliché which would become a widely accepted myth about Whitman in Europe, namely that the American author was better understood and more appreciated by Europeans than by his own people:

By the way, the German public seems to be better prepared to understand [Whitman] than his own countrymen who lack the sensuality and intuition in order to grasp all of the beauty of this new poetry. But the day will come when the Americans, they too, will understand. ${ }^{28}$

This idea of the superior ability of Europeans to comprehend Whitman's works has become a recurrent feature in certain, less disinterested European criticism on Whitman -and in later periods it has been especially useful for anti-American purposes. Americans, so the argument goes, are unable (and unwilling) to understand the best of their sons.

The discussions centering on Whitman's homosexuality are another example of how the acquaintance of the Frenchman and the German became relevant to European Whitman reception at large. In 1905, Eduard Bertz attempted to prove Whitman's homosexuality in a long, fifty-page article in the Fahrbuch für sexuelle Zwischenstufen, ${ }^{29}$ a yearbook devoted to the reform of German gay laws. Johannes Schlaf, who mistakenly took this article to be a full-fledged attack on and slander of his hero, retorted with a pamphlet ${ }^{30}$ to which Bertz answered in turn with a monographic "study" entitled "Whitman Mysteries." ${ }^{31}$ In the first decade of the twentieth century, then, Whitman's person and work became an interesting factor in the emerging German discussion on gay rights. ${ }^{32}$

In 1913, this discussion resurfaced in France, mainly in the reputable Mercure de France, following the publication of the infamous literary hoax by the French writer Guillaume Apollinaire. Apollinaire gave a fictitious report of Whitman's funeral in which he described the ceremony as one gigantic 
orgy complete with alcohol and homosexual activity. French and FrancoAmerican Whitmanites, including Bazalgette and Stuart Merrill, involved themselves in the elaborate discussion by writing letters to the editor to which Bertz replied with vicious attacks. ${ }^{33}$

Betsy Erkkila, unaware of the German discussion in the previous decade, claims that the French were "the first country to make Whitman's sexuality a cause célèbre. ${ }^{\text {"34 }}$ However, the Schlaf-Bazalgette exchange proves that the Frenchman was fully informed of the German discussion on Whitman's "anomaly," mainly through his friends in Germany and Austria, and that he had an indirect part in it as early as 1905.

Apparently, Schlaf queried Bazalgette on what were to him troubling allegations of Whitman's homosexuality. Bazalgette had already heard about Bertz's book through his friend Stefan Zweig, ${ }^{35}$ one of the most significant Austrian writers of the first half of the twentieth century who also seems to have supplied Bazalgette (and other French poets) with news about Whitman reception in German-speaking countries. Bazalgette's reply to Schlaf expressed his severe doubt about the validity of Bertz's approach-without, however, Schlaf's violent defense of Whitman as a heterosexual:

I suppose from what I know about it, that [Bertz] is one of these idiotic hunters for anomalies of which there are many at the present moment. I know very well what manly love means in Whitman's works and he must be stupid to accuse the man who is maybe the most normal who ever appeared on the planet to be inverted ["un inverti"]. I am glad to hear that you are preparing a reply to this dog who amuses himself on account of what he does not understand. Do you know the sensible page written by Havelock Ellis on this point in his book Studies in the Psychology of Sexual Inversion? ${ }^{36}$

In a later letter he added to these strong words:

These people of the school of Lombroso, Kraft-Ebing [sic], Nordau are so occupied with denouncing sexual inversion and the madness existing in the world that they forget to look at themselves to see how alienated [alienés] they are themselves! ${ }^{37}$

Bazalgette is of course wrong in assuming that individuals like Krafft-Ebing or Bertz wanted simply to "denounce" homosexuality, a misunderstanding also held by Schlaf, who wanted to "clear" Whitman's name of any suspicions on that account. His correspondence with Schlaf, however, shows that these issues were raised and discussed among Europeans of different national origins and that the development of certain views concerning Whitman was a result of this intercultural discussion.

The Schlaf papers also contain a letter on this matter by H. B. Binns, although the Englishman, having visited the U.S. and talked to Traubel and other members of the Fellowship, was a lot more guarded in his statement: "The question you raise about Calamus $\&$ Doyle is one of the most difficult of all; I have said little about it [in my book]." ${ }^{38}$ The debate on Whitman's ho- 
mosexuality emerging from the Schlaf papers is thus shown to be one in which Whitmanites from different countries were involved and is an important example of the intercultural nature of European Whitman reception.

What appears most forcefully from Schlaf's correspondence is the idea of a transnational movement which would transform European society and art. In the various letters, the "progress" of the movement on a European scale is always an important topic, whether it would be in their own countries or in Italy, Great Britain, or Scandinavia. In the correspondence, Stefan Zweig, Emile Verhaeren, Henri Guilbeaux, Francis Vielé-Griffin, Jules Romains, and many others figure prominently as ambassadors of an emerging spiritual but never officially institutionalized "Fellowship." When Binns wrote to Schlaf about the latter's translation of his biography of Whitman into German, ${ }^{39}$ he stated in a characteristic manner: "I am proud to think that we shall thus become collaborators in the great cause of Liberty and Fellowship." 40 In 1909, the French poet Henri Guilbeaux informed Schlaf of a

conference on Walt Whitman at the université populaire du faubourg St. Antoine. . . . We received Verhaeren at the St. Lazare train station and we went to dinner together with him, Bazalgette, Romains and myself. We talked about you for a long time. . . .11

In spite of the fact that Schlaf did not travel much, he was-because of the interest in Whitman among many of the French writers of his time-an accepted member of their community. He translated them into German ${ }^{42}$ and facilitated their positive critical reception there. In turn, his writings were translated and propagated in French-speaking countries.

Schlaf regularly reviewed publications of French Whitmanites, at times comparing them with what he felt to be the insufficient attention given to Whitman in Germany. In an article on "Walt Whitman in France," Schlaf stresses that Whitman's introduction to Europe

is not just a passing literary sensation but one of the most significant and future-oriented results of the development of human culture. . . . A few years ago, they [the French] started to pay more serious attention to him: today, there are already public lectures on him. Not only that: around his name - and that of Emile Verhaeren at the same time-a new, very promising poetic generation is assembling. . . . It is not exaggerated when we say today: in five years from now there will be a new poetry in France which will put an end to the decadence in poetry and the formalistic artistry! A poetry which will again be expressing a Weltanschauung with a decidedly new religious dimension will become the cultural center of new cultural modernism ["Moderne"]. ${ }^{43}$

Whitman reception for Schlaf, as for many of the other devotees, was therefore much more than simply the introduction of an American author into the European literary scene. It was a philosophical and religious undertaking in which representatives of different cultures worked together. It is maybe the most remarkable achievement of European Whitmanites to have established this genuine rapport in artistic and other domains - a cooperation which was 
intense and was destroyed only by the renewed and fatal nationalism that came about as a result of the First World War. ${ }^{44}$

In an intercultural study of Whitman's reception, many dimensions of culture have to be considered: the religious dimension; the political dimension, especially in view of the radically leftist orientation of some of the early Whitmanites; the sexual dimension, which is obviously one of the most important in international Whitman reception; and, of course, the literary dimension. An intercultural study of Whitman reception could be a most effective way to study the interconnectedness of what we have come to know as the "modernist" movement in literature, "the new trend toward an international community of art." 45 In this way, the history of Whitman's reception is not a mere accumulation of facts but becomes the study of relationships between individuals and their cultures: proof of the creativity inherent in intercultural contacts and the extraordinary ability on the part of Whitman and his followers to inspire and facilitate them.

\section{Karl-Franzens-Universität, Graz, Austria}

\section{NOTES}

1 Harold Blodgett, Walt Whitman in England (Ithaca: Cornell University Press, 1934).

2 Harry Law-Robertson, Walt Whitman in Deutschland (Gießener Beiträge zur deutschen Philologie, 42; Gießen, 1935).

3 Betsy Erkkila, Walt Whitman Among the French (Princeton: Princeton University Press, 1980).

4 Roger Asselineau and William White, eds., Walt Whitman in Europe Today (Detroit: Wayne State University Press, 1972). This supplement to the Walt Whitman Review contains articles on Whitman's reception in more than ten countries.

5 The conference "Walt Whitman and the World," sponsored by the Walt Whitman Association and Rutgers University, Camden, included contributions on Whitman in Latin America, the German-speaking countries, the Soviet Union, and China. These papers will be published in a forthcoming issue of The Mickle Street Review.

6 Frederik Schyberg, Walt Whitman, trans. Evie Allison Allen (New York: Columbia University Press, 1951; original Danish publication, 1933).

7 I am presently preparing an extensive study on Whitman in the German-speaking countries.

8 Augsburger Allgemeine Zeitung, 12 and 19 June 1868.

9 Ferdinand Freiligrath to his daughter Käthe Freiligrath, 2 December 1868, published in Luise Wiens-Freiligrath, ed., Freiligrath-Briefe (Stuttgart, Berlin: Cotta, 1910), 167-168. The version quoted here is my own translation, as are all the translations of foreign-language letters quoted in this essay.

10 Clara Barrus quotes from the letter and locates it in the Bliss Perry Whitman collection; see Barrus, Whitman and Burroughs: Comrades (Boston: Houghton Mifflin, 1931), 40. 
11 See Eduard Bertz, "Walt Whitman. Ein Charakterbild," in Fahrbuch für sexuelle Zwischenstufen 7 (1905), 171-173.

12 See Amalie von Ende, "Whitman in Germany," New York Times Saturday Review, 9 March 1907, 146.

13. The Schlaf papers are presently in the process of being catalogued by Ingolf Schnittka, who is preparing a Ph.D. thesis on Johannes Schlaf. I am indebted to Mr. Schnittka and Mr. Hartman, director of the Querfurt museum and archive. This essay is the result of a research stay in the German Democratic Republic. For generous advice, assistance, and inspiration, I am indebted to Marianne Müller and Kristina Hülß of the Department of English and American Studies, Humboldt University, Berlin.

14 Schlaf has frequently been mentioned in connection with Whitman's reception in Germany, but nobody has given much attention to the extent and exact character of Schlaf's role as the leading German apostle. The Schlaf papers have not previously been consulted in relation to this topic. See also Ward B. Lewis, "Walt Whitman: Johannes Schlaf's New Being ('Neuer Mensch')," Calamus 6 (1972), 22-34, reprinted in Revue de Littérature Comparée 44 (1973).

15 Traubel to Schlaf, 16 June 1904 . Unless otherwise indicated, all letters are located in the Querfurt museum and archives.

16 Johannes Schlaf, Walt Whitman (Dichtung, 18; Berlin: Remer, 1904).

17 Walt Whitman, Grashalme, trans. Johannes Schlaf (Leipzig: Reclam, 1907).

18 Amalie von Ende was a New York-based journalist in literary matters and a mediator between German and American culture. A German-American with a socialist-anarchist background, she had been active in the Walt Whitman Fellowship International as early as 1903 and in 1907 became a member of its board of directors. She made use of her role as American correspondent of the influential German literary periodical Das literatische Echo in order to further Whitman's popularity in Germany. The German audience depended a great deal on her for their knowledge of American Whitmania.

19 Ernest Crosby to Schlaf, 8 April 1906.

20 Crosby to Schlaf, 8 April 1906.

21 Walt Whitman Fellowship Papers, 10 (Philadelphia, 1904), 7.

22 Bazalgette to Schlaf, 8 March 1904 (orig. French).

23 Bazalgette to Traubel, 18 January 1907 (orig. French).

24 Bazalgette to Schlaf, 27 January 1907 (orig. French).

25 Bazalgette to Schlaf, 7 August 1908 (orig. French).

26 Bazalgette to Schlaf, 15 May 1907 (orig. French).

27 Bazalgette to Schlaf, 3 March 1907 (orig. French).

28 Bazalgette to Schlaf, 15 May 1907 (orig. French).

29 See note 11.

30 Johannes Schlaf, Walt Whitman Homosexueller? Kritische Reflexion einer Whitmanabhandlung von Dr. E. Bertz (Minden, 1906). Schlaf's copy of Bertz's 1905 article (part of Schlaf's library in Querfurt) is inscribed to him by Bertz. However, Schlaf seems to have felt only disgust for this study as his many violently derogatory marginal comments indicate.

31 Eduard Bertz, Whitman-Mysterien. Eine Abrechnung mit fohannes Schlaf (1907). 
32 I am indebted to Hans-Joachim Lang of the University of Erlangen-Nürnberg, for information about the discussion of homosexuality surrounding Whitman as well as for much assistance in the general field of Whitman reception. See Lang's "Bertz vs. Schlaf: Whitman's Homosexuality in Germany," in Frank L. Borchardt and Marion C. Salinger, eds., A Conversation in the Life of Leland R. Phelps (Durham: Duke University Center for International Studies, 1987), 49-86. On the same topic, see Robert K. Martin, The Homosexual Tradition in American Poetry (Austin: University of Texas Press, 1979), and "Walt Whitman and Thomas Mann," WWQR 4 (Summer 1986), 1-6.

33 Erkkila, 199ff.

34 Erkkila, 200. The international nature of the debate on Whitman's homosexuality is touched upon in Francis Oakes, "Toward Destroying a Myth," Walt Whitman Newsletter 2, no. 3 (1956), 19-21.

35 Bazalgette to Schlaf, 22 November 1905 (orig. French).

36 Bazalgette to Schlaf, 22 November 1905.

37 Bazalgette to Schlaf, 10 December 1905 (orig. French).

38 Binns to Schlaf, 5 November 1905.

39 Published as Walt Whitman. Ein Leben (Leipzig: Haessel, 1907), with a two-page introduction by Schlaf.

40 Binns to Schlaf, 20 April 1906.

41 Henri Guilbeaux to Schlaf, 7 February 1909 (orig. French).

42 Schlaf was one of Verhaeren's German translators.

43 Johannes Schlaf, “Walt Whitman in Frankreich,” Nord und Süd 133 (1910), 502-503.

44 French-German intercultural contacts steadily intensified up to the outbreak of the war. This becomes obvious in the case of the Alsatian expressionists René Schickele and Ernst Stadler, both of whom were also interested in Whitman.

45 Erkkila, 237. 